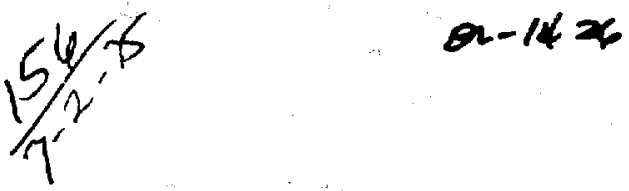

\title{
GAS PRESSURE FROM A NUCLEAR EXPLOSION IN OIL SHALE
}

R. W. Taylor

April 9, 1975

Prepared for U.S. Energy flesearch \& Development

Administration under contract No. W-7405-Eng-48

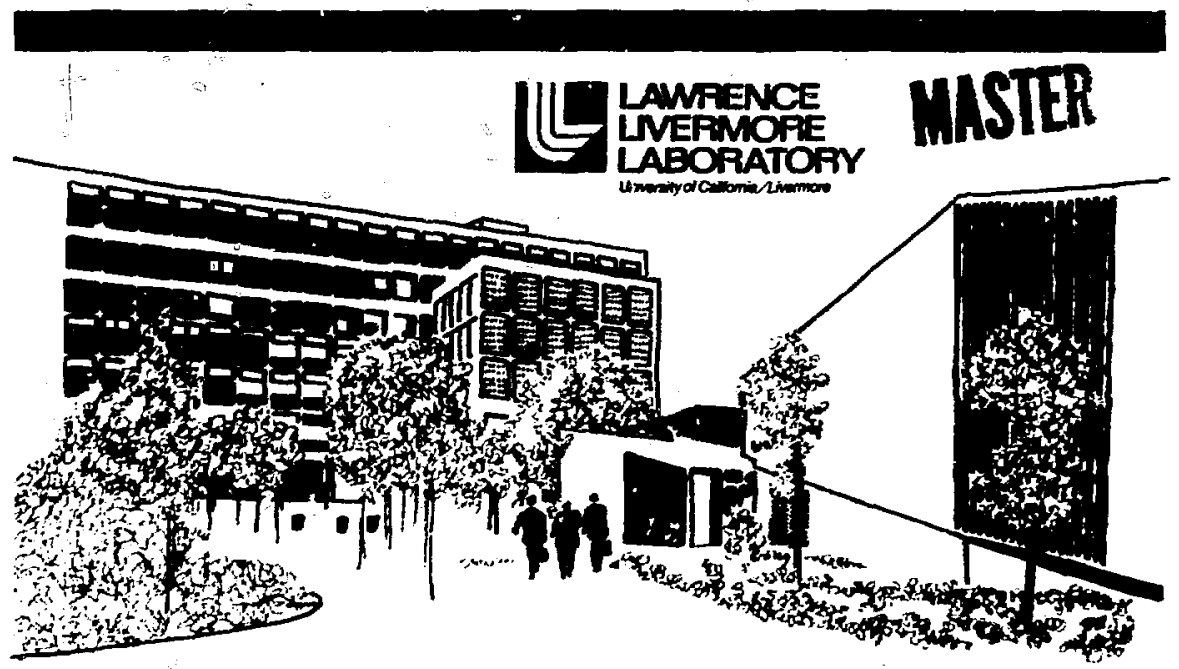


Notice:

"This report was prepared as an eccount of work sponsored by the United States Gavernment. Neither the United States nor the United States Energy Reserch \& Devtlopment Administration, nor any of their employees, nor any of their centractors, subcontrectors, or their empluyees, makes any ururenty, express or inplied, or assumes any legal lisbility or responsibility for the sccuracy, completenes of usefulnesy of any information, apperates, product of process disclosed, or represents that its une would not infringe pirvately-owned riplst."

Printed in the United States of America Available from

National Technical Information Service U.S. Department of Commerce 5285 Port Royal Road Springfield, Virginia 22151

Price: Printed Copy $\$$ *; Microfiche $\$ 2.25$

\begin{tabular}{l} 
*Pages \\
\hline $1-50$ \\
$51-150$ \\
$151-325$ \\
$326-500$ \\
$501-1000$
\end{tabular}

NTIS

Selling Price

$\$ 4.00$

$\$ 5.45$

$\$ 7.60$

$\$ 10.60$

$\$ 13.60$ 


\title{
迎 \\ LAWPENCE LNEFAMOPE LABOPATOAY \\ University of Callomid 2 , vermore Callomia 94550
}

\section{UCRL-51795 \\ GAS PRESSURE FROM A NUELEAR EXPLOSION IN OIL SHALE}

\author{
R. II. Taỵlor
}

IIS. date: Apr11 9, 1075

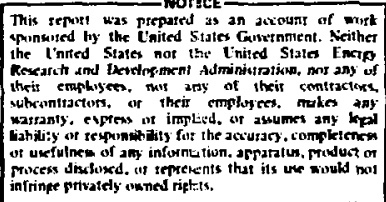




\section{content:}

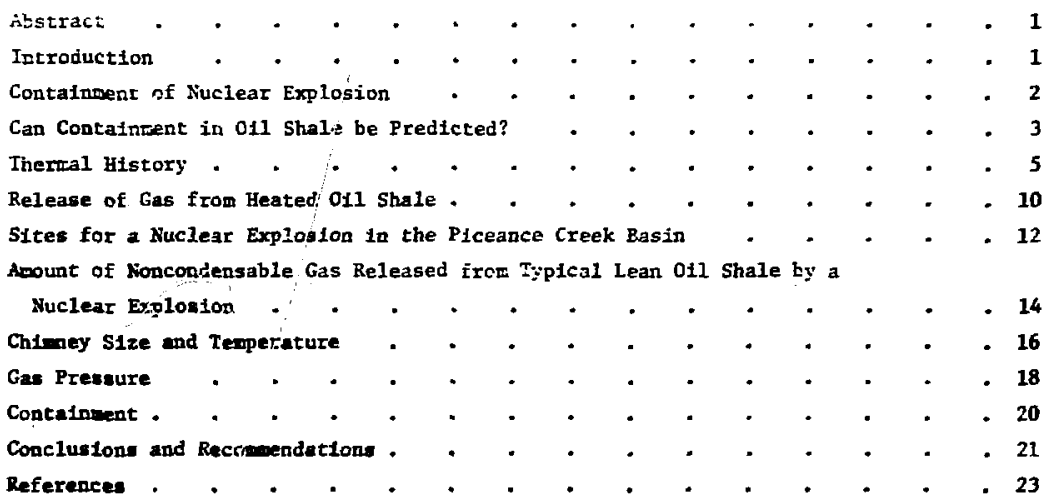




\title{
GaS PRESSURE FKIN A NUCLEAR EXPLOSION IN OIL SHALE
}

\begin{abstract}
In this report we escimate the guantity of gas and the gas pressure resulting from a nuclear explosfor in oil shale. These estimates are based on the thermal history of the rock diring and after the explosion and the amount of gas that ofl sinale releases when heated. We estimate that

for oil shale containing less than a fez percent of kerogen the gas pressuze wll be lower than the hydrostatic pressire. A field prozrain to jeternine the effects of nuclear explosions in rocks that situlate the iniogue features of oil shale is recormended.
\end{abstract}

\section{Introduction}

The use of nuclear explosives to fracture ofl shale has been under consfderation for wore than 10 years. The idea developed into an In situ ol1-recovery scheme called Project Bronco, a joint effort of the U.S. Bureau of MInes and the Lawrerce Ifvermore Laboratory. ${ }^{1}$ Recently the Idea was reconsidered as Project licah, ${ }^{2}$ but neither of these projects was carriec out.

Because of the recent increase in the value of oil, the recovery of oil from shale is wore attractive than ever. A1though a large amount of ofl shale can be mined by corventional techiques, most of the vast oil shale reserves in the United States are too deep to be recovered in this wy. According to a recent scudy 3,4 that takes into account advances in the use of nuclear exploatves since the tine of Project Bronco, the ure of ruclear explosive appears to be the least expensive way of recovering oil from deep shale.
Wiat stands in the way of starting a progran to find out whether it pays te use nuclear explosions to recover ofl from ofl shale? The principal tecinical problem seems to be safety. Before the IIrst nuclear explosion can be deronated ir oil shale, we wust be reitaln that the radscactive products of a nuclear explc son will rewain underground. ifter sote underground nuclear expiosions, escaping gas has brought soild and gaseous radioactive materials to the surface. The greater the arwount of gas released by a nuclear explosion, tine sore likely it is that some wizl escape to the sirface. The arount of gas relinased is related to che apount of volatile matter in tha rock. oll shale contalns arganic satter, which releases gas when heated; it al io contains water and carbonates. Figure 1 shows how much wore gas is releasad at $1000^{\circ} i$ by vil shales than by other rocixs.

In this report we estinnte the pressure that will result froin a nucleer 


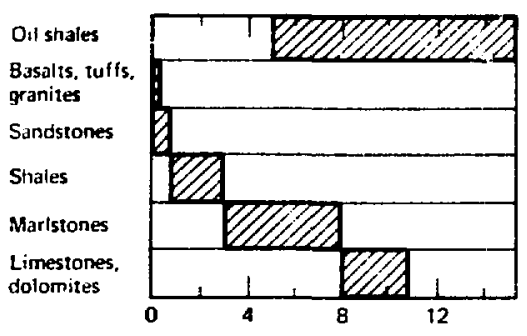

Nencondensable gas reledsed at $1000^{3} \mathrm{C}-$ moles. $\mathrm{kg}$

explosion in oil shale. The estimate is based on our current understanding of the anount of rock heated by a nuclear explo-

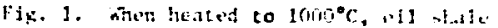

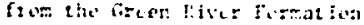
ruleaso: tore nowemcensole (dr: j

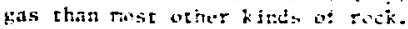
The shaded areas roresint tike ranges for the weritus inds at sock.

\section{Containment of Turlear Explosions:}

"Containment" is jargon for the tecitnique of keeping underground the gases released from zock by nuclear explostons. Although the bulk of it is not radioactive, this gas can sweep radioactive gases and solid particles to the surface, creating a possible health and safety hazard to workers in the area. Under certain wind condftions, the rapidly released radtoactive gas may be wept across international boundarfes, thus violating international agrewents. In the past, contaloment faflure has occurred in two ways: dyanic ventiris and seepage.

Dyneate venting is the rapid loss of hot gas, watly steam, during the first 30 an or so after a nuclear explosion. Th1s kind of venting occure mostly through a few f1esures that wy or wy not have been present before the explostor.

The scaled depth of burial is perhap: the sost important factor in preventins dyoanic ventiag. Experience has show sion and on laboratory detersinations of the amount of gas released by heated oil shale. that explosions will generally be contained at scaled depths of $>120 \mathrm{w}^{1 / 3}$ meters, where $W$ is the yield in kilotors.* Dyramic venting cannot occur in a dry silicate rock free of carbonates and other volatile materials because all the gas is condensed ro a liquid at temperatures ox about $3000^{\circ} \mathrm{C}$. Cooling to $3000^{\circ} \mathrm{C}$ Is rapid because of the loss of heat by radiation to che surrounding cooler rock.

In an experfment ramed Salmon, a nuclear explosion was detonated in pure salt. Because of the lack of volatile materials a vacuun was found when the cavity was drilled into." In contrast, an earlier nuclear explosion in a salt forwation that contained beds of wet clay (the Gnowe experivent) produced dynalic

*In the Internarional syaten of Units (SI), the unit for energy is the foule. A 1-kt nuclear exploetion correspond to 4.18 $\times 10^{12} \mathrm{~J}$, or 4.18 terajoules (TJ). 
venting of scens, for alout a day after the exolosion."

Just how muci: volatice material a rock can contain befcre venting occur: is no: well knohn even for an area as woll studjed as the Nevada Test Sice. Presently, the testing of nuclear explosions is hol corducted at sites containing rore likin about $5 \mathrm{wt} \% \mathrm{CO}_{2}$ as carbonates.

Inhomogeneities in rock, such as faults, joints, and bedding planes, fan be narural zones of weakness, but close tu the explosion they seem to be sealed by shock waves. It is very difficult to quantify the integrity of the rock at the site of an explosion.

Emplacement engineeriag has been developed to prevent dynamic venting in cases where the volatile-matter content of the rock is below established eapirical Isits. It has been difficult and expensive to learn to avoid dynaxic venting due to fallure of steming and other manade structures, particularly in the case of shallow low-yield explostons and in the cast: of explostons emplaced in tunele. Gas leaks alcas cahins usto ca be comon. Ihey are aycided now by cabje blocks, a

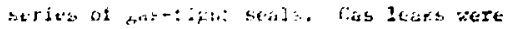
gencraily low itains at gas walec seepb.

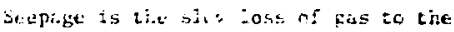
atmosphere frot ile site ai a nirleár

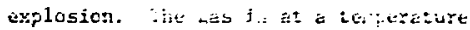
aejow iono and is probatly coposed tost?

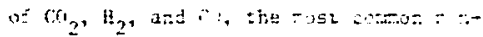

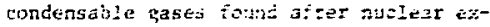
plosions in rost kires el rez. in pos:-

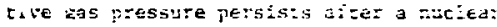

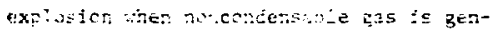

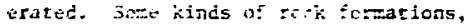
particularly the low-censity twif and a11:3iu at the Je:ala Test Site, have

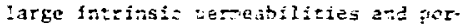

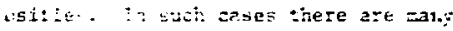

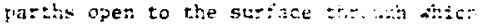
gias can zow iZ a pas pressute pezsiszo.

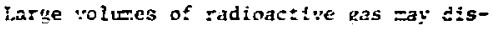
piace the oir in the roci bormetions ard Itse1! remfin bolow the surtace. The ait is not detected becal. : it seeps out of the ground over a iide ar:a. hinen sine volume of sorcrideasabit gas exces. t:te

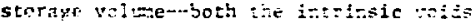

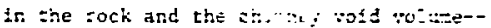
seepage say octur. dest inf on tie

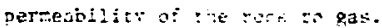

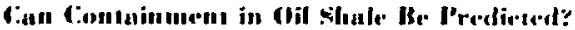

From faeld expe: ierce the have :earnue

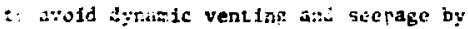
astrleting the citer of nielea: explosions to certaln familfes of rocks: i:antie, basalc, dry tuff, and lowmolat:le (lowcarbonate) aliuvlus. In order to appi what we have jearned to ofl thale, certita zEtExeI fectark mist be consldered. including the arwount of rock huted, the tesperature $:$ shich it is heated, and the duration of the heating: These thinge

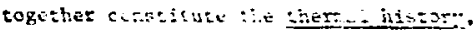
which is probagly the teast raco diped of

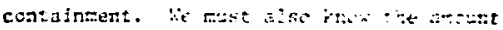

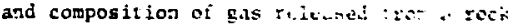

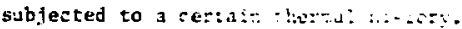

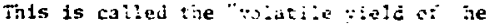

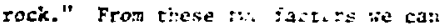
estimate tre : at a an-... $\sigma^{2}$ is produced.

To estignte the oas pressure. we rust anok (1) : l.e voic volume available undergrount (or tib gis, (2) the temperature of 
the gas in this vold, and (3) the permeabilfty of the surrounding rock. If the gas prensure exceeds the lithostacic pressure for very long, fracture oi the rock will probably occur. (This is the basts for lising fluid pressure to crac: rock in ofl and gas production.) A gas pressure higher than the hycrostatic pressure fay te saž is one rock but lead tc displacenent of water and gas release in another.

The oil shale in the Piceance Creek Basin in colorado is very dense and impermeable at the top of the Parachute Creek Yesber and at the edges of the basin." Deeper in the sawe nenber, near the center of the basin, is a leactied zone that way be very permable to gas, particularly fi it is dewatered (as it must be for retortIng). ${ }^{3}$ At such a site a high gas pressure: probabiy cannot develop. The feastaslity o: Eracturing c:il haile by nuclear expsosicas w111 presably be cesced at the edges $c$ f the basta. where the perseability is :ow enougin to prevent chimney flooding. At stcis sites the perseailitity ay be toc low to allow chiney depressurization by subsurface gas flow. In any case. we cannot be wure of the feasibility of fracturing oll shale by ruclear explosings unt 11 furtier we11-1nstrumented containsent experfuents are conducted at the Nevada Test site or elsethere in an impermeable carboate-rlch rack, preferably * furlscone.

ite can predice the utorage volue avatlable to the gas, at leset the exploston-produced vold volum, to within about 20\%. However, we catnot predict the mount of ges that $w 111$ be released by a nueleat explonion with nerrly the sene eccuracy, partly because we are not certafn abeut the fimoine of roek hesed ty a rigclear explosice or the quasiley vi ga- released by roxis an heaziteg.

his halle bcesiale to measure the inount of gas. fiost $1 ;$ to... released by hed: ir tire tase of the taree gas-stimulatir: nuclear experiouncs fistugs:, Rulison, ars Sto Blance. In tion caste of bots Gasbeggy and Rulison, early estfates ot the cotal arounts of $\mathrm{CO}_{2}$ based on measuretrents o: the concentratfons of railoactive gas cracers havf: subsequently heen coni irmed by observarions of acrual gas production. $\vec{f}$ In the Kio Blanco experifert, the awount of gas released has beer calctiated frow measurerents of the concentrat $x$ ons of gas tracers. but the gas production to date has been ltmiced.

The yield of volazile water fros kf: Ilanco rocks has been measured by laboracory pyrolysts experinents. By comparing tha amount of zas relased by iaboratory pyrolysis to the asount of pyrolÿstsproduced gas tound after the explostor, we ave est inaced the arount af roik heated and degataed by the explestion. ${ }^{B}$ These reasuremens tend to confir: the theoret;cal model for the thermal hiscory of nuclear explosions presenzed in Secticn IV.

Kecent attempts to predict and seasure the anount of gas released by nuclear e:plosions ac the Sevada Test site have been disappilncing. The rocks are of ten very heterogeneous, making prediction dif Eicult. Large varintions in gas-tracer concentrations have been observed betwen aanples taken frow the same hele. Postexplosion ras arples withdram from tubes mplaced before the expioaion indicate thine the rad loactive tracer gaves are not unif ormly aixed with the an released from the rock by the heat of the explosion. 


\section{Thernat Itiotory}

The heating and mejting of : it: by auclear explusions have le.. ro.

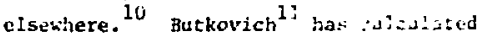
the temperatur. rist ds a $t u t:$ ison of ijisrance for a nuclear explosiut of giver. yjeld in silicate rock of various densitfes. His work was based or: eyperimental Hugcaiot-sype (stock) densit $\%-$ ossuri measurements.

A low-tensiey (i.e., porcus) silicate rock attenuates the shock of ar explosion is a shorter distance than does a highdensity isorporous) rock of the same type. Knowing the =elitigg point of a rock, Sutkovich ${ }^{11}$ calculated the distance out to which rock is melted by the passage of a shock as a furntion of preshot rock denitity. Ot: tr ti:is point the rock is Seated b: the rtock to temperatures above the neliing point. From the heat capacity of rock, the heat of me1:1ng, and othe: data, Butkovich calculated the rotal cia:ity of heas intia!1y jeposited in rocks at the melting poin: and jove as a iraction of the cora? ivolosive energy. He concludes that it: is this Eraction that fs avallabie to heat adisiopal rock to the fiteltitg poirs. It is this guaz:lty of heaz that we essure to be araizabls 12 jede ail shale, is show: latez. First we Fist estimate the energ: iractionaticn for exi state from calculations for silic:te rock.

The assumption is rade that it is the porosity oi a rock, rarier than ricnstiv, that detersines the iultiaj isspositio: of shoct-wave energy. Teile I show's Butkorich's data for a silicate rock it th the same selting point as oil shale $\left(\because 1200^{\circ} \mathrm{C}\right) . *$ The data were cabulated by *Jackson ${ }^{12}$ found tinat cil shale from tise Pireance Creek Basin started to mele at atout $1950^{\circ} \mathrm{C}$ and was conpletely neltes at $1227^{\circ} \mathrm{C}$.

Table 1. Eitect of sillcate-rock censity on tie taction of energ: $0: a$ 4.18-TJ nuclear explcsion deoostted $i:$ jock in rock at temperatures atose the melting paist (1250 $50^{\circ} \mathrm{C}$.

\begin{tabular}{|c|c|c|}
\hline $\begin{array}{c}\text { Vensity } \\
(x / c:)^{4}\end{array}$ & $\begin{array}{c}\text { Porosity } \\
(\%)\end{array}$ & $\begin{array}{c}\text { Enery fraction } \\
\text { 价osited }\end{array}$ \\
\hline 1.4 & 50.0 & $2.7:$ \\
\hline 1.6 & 42.8 & .69 \\
\hline 1.9 & 35.7 & $.6=$ \\
\hline 2.0 & 28.5 & .55 \\
\hline 2.2 & 21.4 & $\therefore$ \\
\hline 2.4 & 14.3 & .39 \\
\hline 2.6 & 7.1 & .30 \\
\hline 2.8 & 0 & 0.20 \\
\hline
\end{tabular}

Goluse percent poronty $=100\{1-(c / 2.8)\}$. The crystalline Lensities of guartz diorite and grante are 2.8 and -2.7 , respectively. 


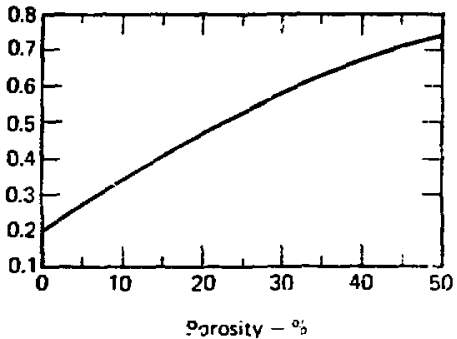

Fig. 2. The higher the porosity of a rock, the greater the iraction of the explosive energy of a $n$ iclear explcsion that is taken to heat rock to melting cemperatures and abova. Shown here is tlie relation fo: a rock hith the relting ter:perature of oil shale $\left(1200^{\circ} \mathrm{C}\right)$.

Butkovich in terms cf density and energy fractionation normalized to a 4.18-IJ explosion. The porosity was calculated from the density. Figure 2 is a plot of energy fractionation versus rock porosicy.

Although oil shale is a very porous rock, wost of Its pores are filled with kerogen. (The bulk density of oil shale decreases from 2.4 to 1.8 as the arount of kerogen intreases fror a few percent to 34 wt;.) We know that kerogen is less cowpressible than afr, but wore compresstble than vold-free (sclid) rock. The shock heating of a rock in wich some Eracrion or whe pores is filled with water (or kerogen) has not yet baen calculated.

For a rough approximation, a kerogenfilled pore in the inorganic matrix of ofl shale 18 asumed to have the same heating effect on shock compression as a pore of half ire volune filled with gas. Because the density of kerogen is approximately

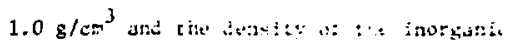

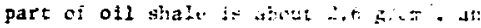

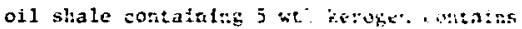

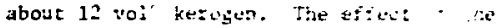
kerogett-tilied pores o: shos theit!ng in tinis example is assined to to the sarme ats that of a purosity of 6 vol, 1.? times the veight percent of kerogen.

Thi gas-filled-pore volume of tite oil Shale ixom the Yahegany Zone of the Piceance Creek Basin in Colorado is atuit $3 \%$, acwrding to laboratory Gaturation ${ }^{13}$ and compression ${ }^{14}$ measuiements. Since the sutura$t i$ a wethod measures only interconnected pores, the results tend to be eirirum values. The satisation method apflied to 11 samples gave an interconnected-porosity range from 0.2 to $12 \%$, with an average of 1.9\%. The compression method consisted of measiring the net volume change of ofl shale as a result of stacic compression to $4 \mathrm{GPa}$ (40 kbar) followed by release to $0.1 \mathrm{MPa}$. The average volure decrease corresponded to a loss of porocit: of $2.6 \%$ (the range for ftue samples was 0.6 to $4.4 \%$ norosity).

These laboratory detezinations of poxosity should robably be considered tu be maximun values because the ofl-shale semples may have party dried ou: during hardling beicre the reasurements inte madt. Shey may not reitresent the porosity of cil shale fn sifu, partictlarly that of o: shale below the water tahle.

The percent porosity of ofl shale tint is effective in inc: ring the localized shock heating, calied the effective porosity $P_{e}$, is prohably in the range

$P_{e}=1.2(* t z$ kerogen $)+(2 \pm 1)$. 


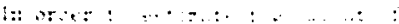

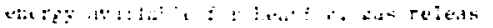

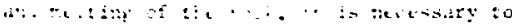

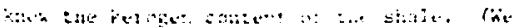

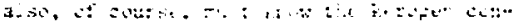

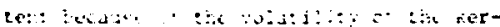

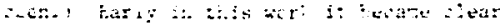

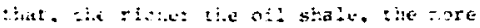

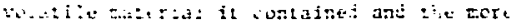
inej: :ar: tonfainnor iculd be a problen. 10 : the re:

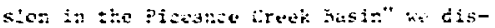
cuss tio camposition c: oi: shait at sone

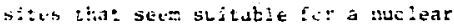

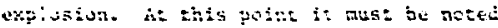

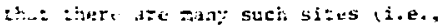

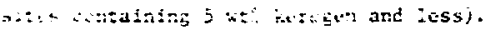

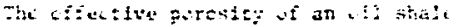

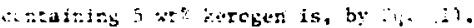

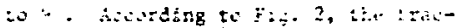

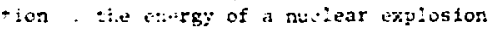

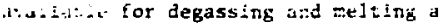

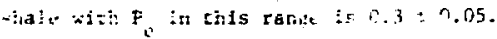

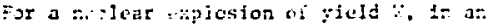

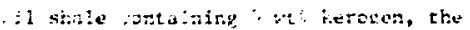

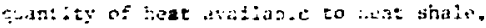

$$
\therefore=(0.3 \quad 0.05) \therefore
$$

In vider :o estizide the sotal atoust of ens relessed ty a nucteaz exploston. we asse estimats thl amotras st zakk heated to rafious terperalures. In disg this we Assume that the cely tuat a ditatis to rafse the temperature of : is Io: is is $\mathrm{U}$. The axount of oll stiale :tin car be heated to some temperature $x$ by bis quantity of heat depends on the hest capacity of the oil shale, the solbiest temperature, and all the varfols heats of transitions (v.g., melti!s and deconpasition) that oil si.ale undergoes when heated.

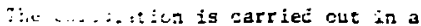

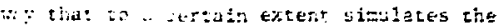

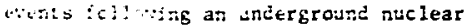
aplosim. - itot tite fass of oil shale

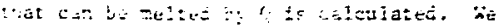

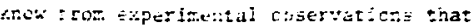

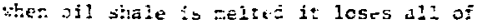

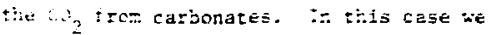
Fist labe inte accoust not anly the TeE

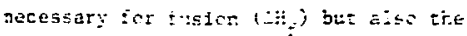
Seat that wit se const:ed by the decorposition of carionates $\left(\mathrm{A}^{\prime}{ }^{\prime}\right.$. The zone is witit relting ceckes is called zone 1 .

lae is inclined to tising st mese zones as ccotatn rolumes if gos hatine : certain gine-a! shai fe.a., spiserica: sinejisj. Huever, becaus ie are divertajo abu*: shimey forwation, rubjic size, and the like, it fs best to cansider tir rones as simply a certain aceur: of rack in a zertain temperature in:etra: the cotal rars of oil staje stat cat be

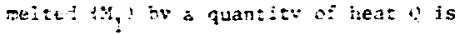

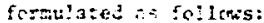

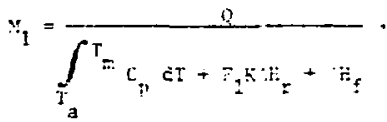

where

$$
\begin{aligned}
& Y_{1}=\text { mass of oil stale in zore } 1 \text {. the } \\
& T_{a}=a-b i e n t \text { temparatur. } 3 r^{\circ} \mathrm{C} . \\
& \begin{aligned}
& T_{L}= \text { melting temperature, } 1200^{\circ} \mathrm{C} . \\
& C_{p}=\text { heat capacity, assumed to be } \\
& \text { constajt, } 1.043 / 8-{ }^{\circ} \mathrm{C}(0.25 \mathrm{cal} / \\
&\left.0^{\circ} \mathrm{C}\right) .
\end{aligned}
\end{aligned}
$$




\section{$E_{1}=$ fraction of the totai catbonate $\mathrm{CO}_{2}$ in the o11 shale In cone 1 released at the temperature of zone 1 ( $F_{1}$ is 3 parameter deter- mined by experiment, as discussed under "Release of Gas irom Heated Oil Shale"). At the melting tem- perature of oil shale, $F_{1}=1$. If decreases to 0 at about $300^{\circ} \mathrm{C}$. \\ $\mathrm{K}$ = weight fraction of $\mathrm{CO}_{2}$ in the ofl shale. It will be stown that an average value for vil shale is 0.15 . \\ $\therefore \mathrm{H}_{\mathrm{r}}=$ heat required to Ielease $\mathrm{CO}_{2}$ from the carbonates in oil shale. According to our $x-r a y$ diffraction measurements, the principal reaction In oil shale that liberates $\mathrm{CO}_{2}$ on long-term heating is the reaction between dolomite and quartz to form diopside ${ }^{13}$ : \\ $\mathrm{CaYg}\left(\mathrm{CO}_{3}\right)_{2}+2 \mathrm{SLO}_{2} \rightarrow \mathrm{CaMg}\left(\mathrm{SiO}_{3}\right)_{2}+2 \mathrm{CO}_{2}$. \\ The heat required for reaction (4) is \\ $\mathrm{sH}_{\mathrm{r}-4}=1.77 \mathrm{~kJ} / \mathrm{z} \mathrm{CO}_{2}\left(423 \mathrm{cal} / \mathrm{g} \mathrm{CO}_{2}\right)$. \\ The exact reaction depenis on the mineral cospesition of the shale. A shale con- tairing only calcite will release $\mathrm{CO}_{2}$ by the reaction ${ }^{13}$ \\ $\mathrm{CaCO}_{3}+\mathrm{SiO}_{2}-\mathrm{CaSHO}_{3}$ (rollastenife)}

The heat required for reaction (5) is

$$
\begin{aligned}
\therefore H_{r-5}= & 2.00 \mathrm{~kJ} / 8 \mathrm{CO}_{2}\left(447 \mathrm{eal} / \mathrm{g} \mathrm{CO} \mathrm{CO}_{2}\right) \\
\therefore H_{f}= & \text { heat of fusion of oll ghale, } \\
& \text { about } 334 \mathrm{~J} / \mathrm{g}(80 \mathrm{cal} / \mathrm{g} \text { of ofl } \\
& \text { shale). }
\end{aligned}
$$

Ii calculating the asount of of: shale heated to other (Iower) tenperatures. the assumption is made that additional oil shale is addet tc the relted rock by collapse, "blowote," and the like, in scch a way tha: the temperature is kept nearly uniform. This assumption wi! not hold if large blocks of oil shale all snto the not region, as they will not be neated uniformly except aiter a long tice. For this reason the arount of rock tiiat is heated to soue temperature calculated by the method oltlined here right be considerad a maximum.

The mass of oil shale heated to temperacures helow the melting poit: is calculaced in $100^{\circ} \mathrm{C}$ temperature zones. In zone 2, which extends from 1050 to $1150^{\circ} \mathrm{C}$, the average temperature $\vec{T}_{2}$ is $1100^{\circ} \mathrm{C}$. The mass of oil shale in zone 2 is

$$
\mathrm{M}_{2}=\frac{\mathrm{Q}_{1}-\mathrm{M}_{1}, \mathrm{CO}_{2}{ }_{\mathrm{T}}^{\dot{\mathrm{H}}}}{\int_{\mathrm{T}}^{\overline{\mathrm{T}}_{2}} \mathrm{C}_{\mathrm{P}} \mathrm{dT}+\mathrm{F}_{2} \mathrm{~K} \Delta \mathrm{H}_{\mathrm{r}}}
$$

Here the term $\mathrm{M}_{1}, \mathrm{CO}_{2} \Delta \mathrm{H}_{\mathrm{r}}$ is the amount of anergy 'ost due to the decorposition of $\mathrm{CO}_{2}$ in the preceding zone $\left(\mathrm{M}_{1}, \mathrm{CO}_{2}\right.$ is the mass of $\mathrm{CO}_{2}$ lost in zone 1$), \mathrm{F}_{2}$ is the fraction of the total carbonate $\mathrm{CO}_{2}$ in the oll shale in zone 2 released at the tenperature of zone 2 , and the other cerms are as defined $i n \mathrm{Eq}$. (3). The term $\Delta H_{f}$ does not appear in any zone after zone 1 because no additional oil shale is melted.

For any zone 1 except zone 1

$$
H_{i}=\frac{Q_{1-1}-M_{1-1, C O_{2}}{ }^{S H_{T}}}{\int_{T_{a}}^{\bar{T}_{1}} c_{p} c T+F_{1} K A_{T}} .
$$


On the hasis of eccnomic cons Iderailons, it appears that an acceptable explosive yteld ${ }^{3}$ for ofI recovery 1 tite Piceanre Creek Bastr is rougity $418 \mathrm{IJ}$. For such an explosion, Q, by Eq. (2), is equal to $125 \mathrm{TJ}$. Taile 2 shows the awount of oil shale, containing $15 \mathrm{wt} \%$ $\mathrm{CO}_{2}$ and $5 \mathrm{wt} \%$ kerogen, thec can be heated to various temperatures by a 418-TJ exp10sion. It also shows the energy lost by the release of $\mathrm{CO}_{2}$ as well as the amount of $\mathrm{CO}_{2}$ released per zone, as expiained in the nexc section. Figure 3 is a bar graph of the ass of cil shale heated to various teiperatures.

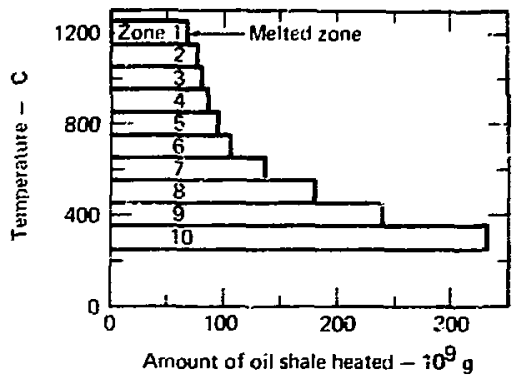

Fic. 3. Amount of oil shale heated to various temperatures by a $418-\mathrm{TJ}$ nuclear explosion. Ambient tenperature is assumed to be $30^{\circ} \mathrm{C}$, and the shale contains $15 \mathrm{kt}$ $\mathrm{CO}_{2}$ and 5 wt\% kerogen.

Table 2. Amount of oil shale, containing 5 wt\% kerogen and 15 wt\% $\mathrm{Ct} 2$ as carbonates, heated to various temperatures iy a $416-\mathrm{TJ}$ nuclear exploston and the amount of $\mathrm{CO}_{2}$ released.

\begin{tabular}{|c|c|c|c|c|c|c|c|}
\hline Zone & $\begin{array}{c}\text { Temperature } \\
\text { range } \\
\left({ }^{\oplus}\right)\end{array}$ & $\begin{array}{l}\text { Mass of shale } \\
\text { to } 20 \mathrm{ne}, \mathrm{M}_{1} \\
\left(10^{9} \mathrm{Gg}\right)\end{array}$ & ${ }_{\left(10^{9}\right.}^{\left.M_{\mathrm{Gg}}\right)}$ & $F_{i}^{a}$ & $\begin{array}{l}\text { Incremental } \\
\mathrm{CO}_{2} \text { jo } \\
\text { released }^{-10^{9} \text { tg) }}\end{array}$ & $\begin{array}{l}\text { Energy } \\
\text { lost by } \\
\text { C02 release } \\
(\overrightarrow{I J})\end{array}$ & $\begin{array}{c}\text { Energy } \\
\text { avallable } \\
\text { In } \\
\text { each zone } \\
\text { (TJ) }\end{array}$ \\
\hline 1 & $1150-1250$ & 69.0 & 69.0 & 1.0 & 10.4 & \pm 8.3 & 125.4 \\
\hline 2 & $1050-1150$ & 37.7 & 8.7 & 1.0 & 1.30 & 2.31 & 107.1 \\
\hline 3 & $950-1050$ & 82.2 & 4.5 & 1.0 & 0.680 & 1.20 & 104.8 \\
\hline 4 & $850-950$ & 87.8 & 5.6 & 1.0 & 0.84 & 1.49 & 103.6 \\
\hline 5 & $750-850$ & 96.0 & 8.2 & 0.99 & 1.22 & 2.15 & 102.1 \\
\hline 6 & $650-750$ & 108.0 & 12.0 & 0.86 & 1.55 & 2.75 & 99.9 \\
\hline 7 & $550-650$ & 138.4 & 30.4 & 0.41 & 1.87 & 3.31 & 97.1 \\
\hline 8 & $450-530$ & 183.9 & 45.5 & 0.08 & 0.55 & 0.97 & 93.8 \\
\hline 9 & $350-450$ & 241.2 & 57.3 & 0 & 0 & 0 & 92.8 \\
\hline 12 & $250-350$ & 330.5 & 89.3 & 0 & 0 & 0 & 92.8 \\
\hline
\end{tabular}

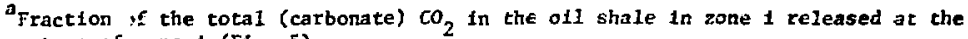

temperature of zone 1 ( $\mathrm{Fig}_{\mathrm{g}}$ 5).
bihe tetal amount of $\mathrm{CO}_{2}$ released (the sun of this colum) is $18.4 \times 10^{9} \mathrm{~B}$, or $.19 \times 10^{6}$ noles.
} 


\section{Helestre of Gas from Heuted ail whale}

In the preceding section an estimate was mode of the amount of shale heated to various temperacures by a nuclear explosion. This section deals with the arount of gas released by oil shale when it is beated.

011 shale contains three components that yield volatiles: water, kerogen, and carbonates. When o11 shale is heated, gas 18 released at temperature from 100 to $1200^{\circ} \mathrm{C}$. Up to about $250^{\circ} \mathrm{C}$, the principal gas released is steam. From 250 to $530^{\circ} \mathrm{C}$, kerogen is converted to hydrocarbon gas and char. Host of this hydrocarbon gas w11 condense to ofl if it is cooled. The reniaing gas is $\mathrm{H}_{2}, \mathrm{CH}_{4}$, other 11ght hydrocarbons, $\mathrm{CO}_{2}$, and $\mathrm{CO}$. At temperaatures abcve about $530^{\circ} \mathrm{C}$, carbonates decompose, releasing $\mathrm{CO}_{2}$. The equilibrim $\mathrm{CO}_{2}$ pressures that can be seneraced by the thermal decompontion of carbonates in oll shale are shown as a function of temperature and carbonate mineralogy in F1g, 4. At temperatures above $800^{\circ} \mathrm{C}, \mathrm{CH}_{4}$ and other hydrocarbons decompose to solld carbon (char) and hydrogen. Also above about $B 00^{\circ} \mathrm{C}$, carbon nay; be gasified by reactions with $\mathrm{CO}_{2}$ or $\mathrm{H}_{2} \mathrm{O}$.

a serles of experitents and calculations have been forde to dezermine the amount of gas that is liberated from oil shale by these various processeg. This work is presented in a complementary report. 15 Samples of $\mathrm{rlch}$ and lean oll shale were heated in closed vessels at varlous temperatures and pressures for various tines, and the amnunt and composition of gas released were messured. The decompositions of kerogen and carbonetes

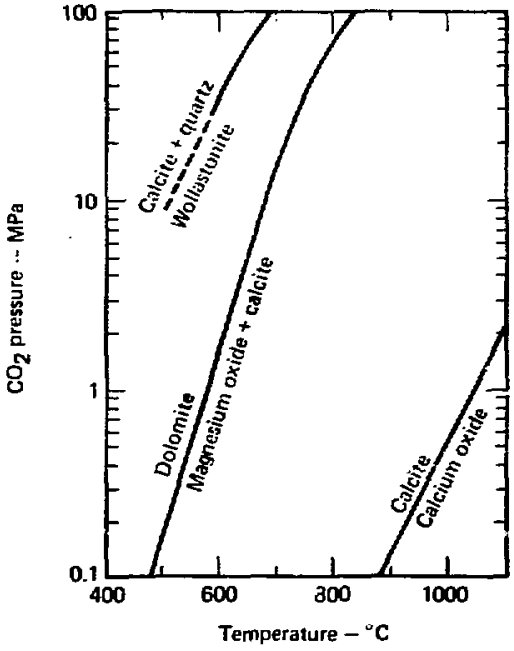

Fig. 4. Equilibrtum $\mathrm{CO}_{2}$ pressure for the thermal decomposition of calcite $\left(\mathrm{CaCO}_{3}\right)$, dolowite $\left[\mathrm{Cayig}\left(\mathrm{CO}_{3}\right)_{2}\right]$, and mixtures of calcite, quartz $\left(\mathrm{S}_{2} \mathrm{O}_{2}\right)$, and wollastonite $\left(\mathrm{CaSiO}_{3}\right)$. Pressures that can be generated by the thermal decomposition of the mixture of dolomite and silicates in ofl shale probably are between the curves for dolorite and wollastonite.

were more or less Independent of each other. In other words, the fraction of the total carbonates decompsed after a certain anount of tide at sore telperature is about the sane for rich or Iean o1l shale. The same 1 to true for kerogen decompostition. The results are show in Figs. 5 and 6 .

The theral decolpostion of the carbonates in Green River oil shale is shown 1n Fig. 5. Curve $A$ is for o11 shale herend in its own decosposttion producte 


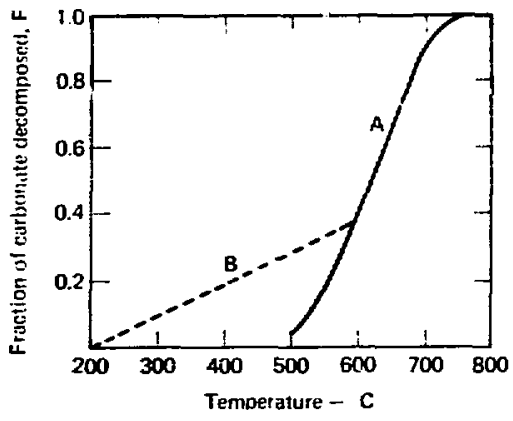

F1g. 5. The fraction of carbonates in oil shale decomposed after heating for -1000 hours. Ine broken curve represents steatenhanced 10w-terperature decomposition.

for w1000 houra. Curve B it an estmate of the low-tenperature enhancement of carbonate decomosition by steam at high prescures. 15 Such conditions are possible in tha caise of limited or delayed chimey collapse.

Figure 6 is an estinate of the amount of noncondensable (dry) gas that way be produced from the kerogen ir Green River oll shale, depending an the environent in which it is heated. For example, if oll shale is heated to $1200^{\circ} \mathrm{C}$ and kept at that cemperature, wost of the kerogen w111 form 011 (if there is a cool place for tt to condense) and char; the asount of gas released is show by curve $A-B$. If o11 ahale is heated to $1200^{\circ} \mathrm{C}$ and there is no place for oli to condense, the hydrocarbon gas w111 be completely pyrolyzed to char and hydrogen (curve $A-C$ ). It il also probable that the char w111 react with $\mathrm{CO}_{2}$ fron the decomposition of carbonates to fort co (curve A-D). If an abundant sup-

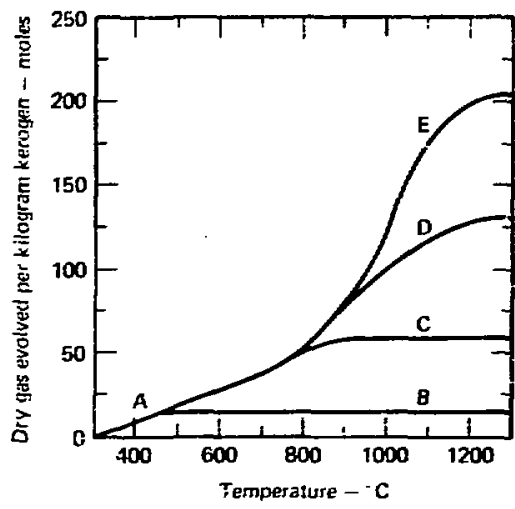

51g. 6. Amount or noncondersable gas released by kerogen as a function of temperature. Curve $A-B$ is for the case where the kerogen produces char and oll. The oll collects in the cool part: of the chiman, and the char avolds further cherical reaction. Curve $A-C$ represents the case where the kerogen is pyrolized to $\mathrm{H}_{2}$ and char at high temperatures, and thus no oll escapes. Curve $A-D$ represents the reaction of char wita $\mathrm{CO}_{2}$ to form 20 at high temperatures, Curve $A-\tilde{I}$ is for the case where char reacts with stean to forc $\mathrm{F}_{2}$ and $\mathrm{co}$.

ply of steam 1s present, char may react -tith it to form $\mathrm{H}_{2}$ and $\mathrm{CO}$ (curve $A-E$ ). e posstbilities are forgulated in

Table 3 .

Each curve in Fig, 5 is a model for various conditions that an prevall in the chimey after a nuciear explosion. It is posible that steam w111 contact hot cher. Curve A-E is used in conjunction with the thermal history (see "Thermal History") to estimate the maximin anount of pas that can be generated by kerogen in 011 shale heated to any given temperature. 
Table 3. Gas generation by the pyrolysis and reactions of kerogen.

\begin{tabular}{|c|c|c|}
\hline Yodel ${ }^{\mathbf{a}}$ & Fomulation & $\begin{array}{c}\text { Net production of } \\
\text { noncondensable ges, I } \approx 1200^{\circ} \mathrm{C} \\
\text { (moles pet } \mathrm{kg} \text { of kerogen) }\end{array}$ \\
\hline$A-B$ & $\mathrm{CH}_{1,6} \rightarrow \mathrm{O} 11+\mathrm{C}+\mathrm{r}_{2}+\mathrm{CH}_{4}+\mathrm{C}_{2} \mathrm{H}_{6}+\cdots$ & 24 \\
\hline$\lambda-C$ & $C: .6 \rightarrow c+(1.6 / 2) H_{2}$ & 58 \\
\hline$\therefore-D$ & $\mathrm{CH}_{1.6}+\mathrm{CO}_{2} \rightarrow 2 \mathrm{CO}+(1.6 / 2) \mathrm{H}_{2}$ & 132 \\
\hline$A-E$ & $\mathrm{CH}_{1.6}+\mathrm{H}_{2} \mathrm{O} \rightarrow \mathrm{CO}+(3.6 / 2) \mathrm{H}_{2}$ & 205 \\
\hline
\end{tabular}

\footnotetext{
a See FIg. 6 .

$\mathrm{b}_{\text {Here }} \mathrm{CH}_{1.6}$ is used as an approxivation for the composition of kerogen and $\mathrm{c}$ represents char.
}

Sites for a Nuelear Explosion in the

Piceance Creek Banin

The best arallable ales for the applicaitou of nuclesr explostons to the eccomic recovery of oil from shale seem to be directly below the rich beds of shale deep in the Parachute Creek Nember of the Green River Formation. Collapse of the vofd blested by the explosive wiII create a vertical cylinder of rubble in which retorting can be carried out. ${ }^{3}$ In order to evaluate the contalneent of the explosion-produced gases, we need to know the content of components that vield valatiles.

Table 4 and Fis. 7 show the redation between the carbonate and the organic atter content of shale alaples collected deep in the basin and frcm eurface outcrope thet probably reprecent lean zones within the formetion. For comprison, the compostions of a sulte of casples frow the Anvil Point: Mine and a anple of shale frow the Mhopany Zone of upper Piceance Creek are also given. The $\mathrm{CO}_{2}$ content was measured by the evolution of $\mathrm{CO}_{2}$ gas when The amount of organic matter in the shale 18 wuch more varlable than the $\mathrm{CO}_{2}$ content. Thick zenes containing less than 10 wtz organic atter are cowon deep in the basin, and locations containing less then 5 wty arganic mater have been found inediately below rich shale; an example It a horizon 46 a thick along upper Piceance Creek at the eastern aide of the basin (see Fig. 7 ).

The water content of fresh ofl shale 1s probably in the range 1 ro 3 wt? regardless of the kerogen content. 15-17 The arount of water reported in chewical analyses depends on the temperature to which ofl shale is heated during the analys is. 15-17

It appears that we can be assured of sttes for nuclear explosions with about 5 wt organic atter: the carbonate $\mathrm{CO}_{2}$ content wIII be neer $15 \mathrm{wt} \%$ and the wacer content will be about 2 wt\%. 
Table 4. Carbonate and orkanfe matter concent of ofi-shale samples collected near the base of the Parachure Creek Yember of the Green Fiver Fornation, the Anvil Points Yine, and the Mahogany Zone of the Piceance Creeic Basin, Colorado.

\begin{tabular}{llll}
\hline Losation & Depth $(m)$ & $\mathrm{CO}_{2}(\omega t \%)$ & Organfe zatter $(n+7)$ \\
\hline
\end{tabular}

\begin{abstract}
Rfo Blanco E-D1 (composite samples)
\end{abstract}

Bronco

(composte samples)
Lean zone $\mathrm{L}-5$, lower Plceance Creek
Garden Gulch Formetion, lower Piceance Creek

\section{Upper PIceance Creek, lean zore}

Anvil Points Mine
Mahofany zone, upper Plecance Creek

640.1 to 670.6

670.6 to 701.0

701.0 to 731.5

731.5 to 762.0

762.0 to 792.5

792.5 to 823.0

823.0 to 853.5

561.4 to 793.4

854.5 to 868.7

908.3 to 929.7

955.6 to 955.9
Surface out- crops (15 파 thick)
Surface out- crops (15 a thick)
Surface out- crops (46 ग) thick)

Mahogany Zone
9.49
11.04
12.26
11.85
10.43
15.55
14.64

16.1

11.8

9.93

15.1

12.25

11.3

13.6

22.0

13.8

11.6

22.0

17.9

13.5

Surface
14.1

13.7
2.9

8.7

1.2

11.5

10.0

8.8

3.6

1.2

1.9

1.9

18.0

17.1

6.9

5.1

7.1

25.8

29.4

15.9

14.2

24.0

A A11 aralyses vere rerformed ae LLL.

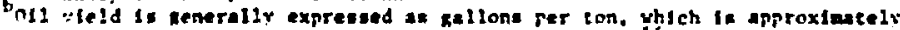

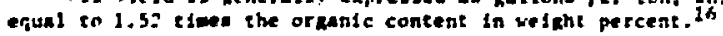




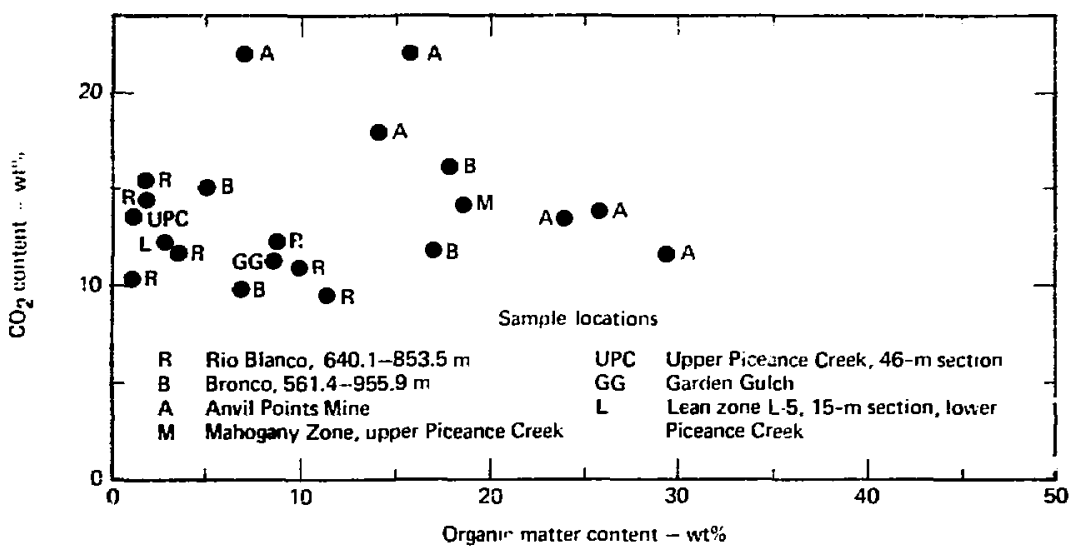

Fig. 7. Velatile content of selected ofl-shale samples fros the Green River Forratior. The weight percent of $\mathrm{CO}_{2}$ is measured by the release of $\mathrm{CO}_{2}$ by actd. The varlation In the organic content is greater than the variation in $\mathrm{CO}_{2}$ content. Sites deep $1 \mathrm{r}$ the basin containing less than 5 kt\% organic material are conson.

\section{Anoun of Noncondensable Gas Released from Typiral I,pan Oil Shale by a Nuclear Explosion}

The production of $\mathrm{CO}_{2}$ from ofl shale nas already been estinated in Table 1. The cse:mate was based on the amount of shale heaced to various ceaperatures (Table 2 and $=1 \mathrm{~g}$. 3) and the experimental factor $F$, shich is the fraction of the total suount of $\mathrm{CO}_{2}$ telased as a Eunction of temperatite (FIR. 5). The total amount of $\mathrm{CO}_{2}$ released by a 418-TJ nuclear explosion from an ofl shale containing 15 wt? $\mathrm{CO}_{2}$ is est1ated to be $13.4 \times 10^{9} \mathrm{~g}\left(418 \times 10^{6}\right.$ toles $)$.

This estiate $1 \mathrm{l}$ based on curve $A$ 15. :32. 5. if the stean pressure is high, C'1 : : released at lorer temperatures than athour atean, as shown by curve D. The cotal awount of $\mathrm{CO}_{2}$ relesed in the pres- ence of steam is $22 \times 10^{9} 8$, $16 \%$ wore than the arount released without sten. Figure 8 shows the total awount of $\mathrm{CO}_{2}$ released from each temperature zone, including the Increnent cuused by steat. The production of gas izom kerogen pyrolysis and reactions can also be estinated in a similar way. The asount of r.oncondensable gas releaser! per kllograr: ot kerogen is given in Fig. 6. The various curves reprasent varfous podels, as explatned under "Release of Gas from Heated 011 Shale." Curve A-E may be tí.e appropriate curve for lean oll shale. It represents the maximu amount of noncondertable gas that can be generated froa 


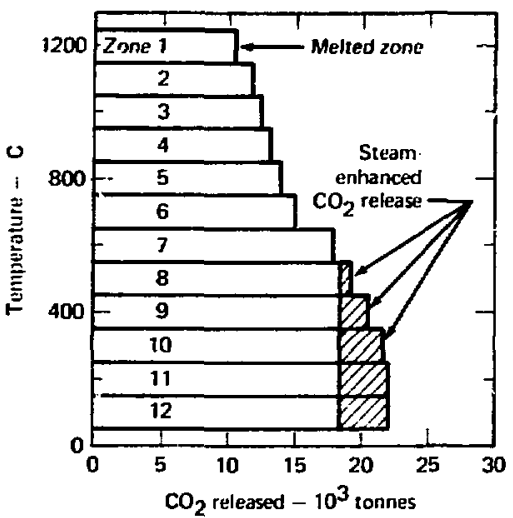

Ffr. B. Amount of $\mathrm{Cn}_{2}$ released from an o11 shale containing 15 wt\% $\mathrm{CO}_{2}$ by a 418-T.T nuclear exploston. The steam-enhanced release of $\mathrm{CO}_{2}$ at low temperatures is indicated. So $\mathrm{CO}_{2}$ is released by rocks heated to temperatures belok $\sim 200^{\circ} \mathrm{C}$. kerogen. It takes into account the reaction of kezozen wth steam at high tewperatures to form $\mathrm{H}_{2}$ and $\mathrm{CO}$. The total amount of noncondensable gas generated from kerogen is egrimated in Table 5. As before, a 418-TJ axplosion is considered, and the first four columas in Tables 5 and 2 are the same. For convenfence, an oll shale contafning 1 wtz kerogen is assumed. The total amount of gas is $189 \times 10^{6}$ moles.

In the case of leap shale, the anoint of gas evolved from kerogen is probably proportional to the ikerogen content. Typ-

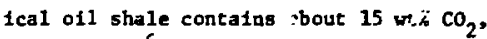
and $418 \times 10^{6}$ moles of $\mathrm{CO}_{2}$ are released by a 418-TJ exploston. Kerogen can contribute more gas than the carbonates when the kerogen content is in excess of 2.2 wt (approximately $3.4 \mathrm{gal} / \mathrm{ton}$ as deternined by Fischer assay, a standard distiletion).

Table 5. Awount of ofl ohale heated to varfous temperatures by a 416-TJ nuelear explosion and anount of noncondensable gas released from kerogen in an o11 thale containing 1 wtz kerogen.

\begin{tabular}{|c|c|c|c|c|c|}
\hline Zone & $\begin{array}{l}\text { Temperature } \\
\text { range }\left({ }^{\circ} \mathrm{C}\right)\end{array}$ & $\left(10^{Y_{1}} \mathrm{G}\right)$ & $\begin{array}{l}M_{1}-M_{f-1} \\
\left(10=\frac{9}{G}\right)^{-1}\end{array}$ & $\begin{array}{c}\text { Gas } \\
\text { evolved per } \\
\text { illogram } \\
\text { of kerogen a } \\
\text { (moles) }\end{array}$ & $\begin{array}{l}\text { Incremental } \\
\text { increase fn } \\
\text { gas in zone } \\
\text { (106 Doles) }\end{array}$ \\
\hline 1 & $1150-1250$ & 69.0 & 69.0 & 195 & 136 \\
\hline 2 & $1050-1150$ & 77.7 & 8.7 & 170 & 15 \\
\hline 3 & $950-1050$ & 82.2 & 4.5 & 120 & 5.4 \\
\hline 4 & B50- 950 & 87.8 & 5.6 & 78 & 4.4 \\
\hline 5 & $250-850$ & 96.0 & 8.2 & 50 & 4.2 \\
\hline 6 & $650-750$ & 108.0 & 12.0 & 35 & 4.2 \\
\hline 7 & $550-650$ & 138.4 & 30.4 & 25 & 3.6 \\
\hline 8 & $450-550$ & 183.9 & .5 .5 & 14 & 6.6 \\
\hline 9 & $350-450$ & 241.2 & 57.3 & 10 & 5.7 \\
\hline \multirow[t]{2}{*}{10} & $250-350$ & 330.5 & 89.3 & $=$ & 1.8 \\
\hline & & & & & 189 \\
\hline
\end{tabular}

Fron curve A-E in Fis. 6. 


\section{Chinney size and lemperature}

The pregsure produced by the gas in the vold volume created by a nuclear explosion depents on the temperature of the gas and the gas comosition (gas compressibility). For the Iirst fet days, the temperature of the gas will depend mosty on the amount of rubble that is foraed and the fraction of the heat of the explosion that is transported to the rubble $b:$ the gas. At present we are not sure hol such rubble will be formed by a nuclear explosion in oil shale. Es:imates can be zade on the basis if avallable experience in other kinds of rock, as correlated by Butkovich and Lews. 18 They have obtained an eapirical relacion that suggests that the larger the vois volume created by an exploston, the Iower wit be tha bulking factor and the nore : abble will form until the rubble -vija, the chimey, is bulked tull. The relation is

$$
3=4.6 \pm R_{c}^{-0.927}
$$

wlere $B$ is the volume fraction of volds 4: : t.e rubile colun (bulking factor) ano R. It the cavtiy radius in meters. A 4I9-r. nuclenr explosion at a depth of son $z$ fi expected to create a $\mathrm{sr}^{\prime}$ rlcal

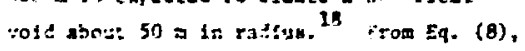
Site titing factor fo: the rubtie created

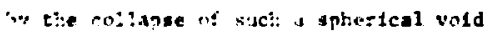
t* 9.223 . The suliking sactors extinated ta chla wy are aterase valuex; aradients weisin * entmray -at orcur.

Fiere have been severa! nuclear explo-

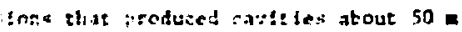

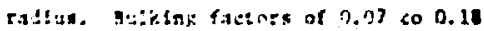

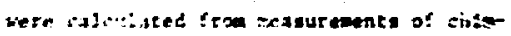

ney hefght and the volume of sisidence craterg in cascs where the chtrncy reacied the suriace. The only avilable data suggesting chimney bulking factors lower than 0.18 are from subsidence-crater-forming explosions in tuff and rhyolize. In tizese cases the bulking factor is calculated by suberacting the volwe of the subsiderce crater from the cavicy volume ans assuming that the difference is distributed in the chimney. (Chimnevs are assumed to grow until they bulk ful.1.) The intrinsic porosity of most tuffs and sowe rholltes is greater than 20\%. ithen large explosionproduced cavities in such rock collapse, soms of the intrinsic porosity way be lost and the density of the rock may increase. Thxs may either increase the chimney height or increase the volume of the subsiderice crater. In such cases the calculated bulkIng factors may be correctly applied to a compressible or frlable rock, but a nodal based on such kinds of rock cannot be extended to less cospressible zypes of rock.

Underground ining cperations have beer. carried out j.n rhyolite and tuff at the Hevada Test SIte and In oll shele Ia the Plceance Creek Dasin. Tunnels in tuff and rhyolite, even a fer atera wide, ans: be supported, wherens orl shale is mined by a roos-and-pillar technique in which the ruone are 18 across. An unupported span of 36.5 was reached in o11 whale in the experibental aine ac anvil Poinrs befoze collapse was observad, and even then the collapse serrad only to give the teat ror. ar arched celling. 19 Hence extenstve sin. caneous collepee of the cartey produce.! :y - nuclear explosion in ofl chale cannct te 


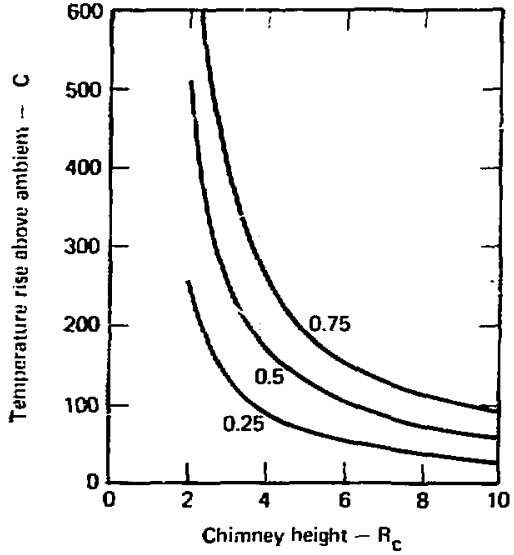

assured. We do not know how wuch rubble 2111 be produced by a melear exploston 1a otl shale.

The nore rubbie produced, the more, rapidly will the gas be cooled, decreasing the likelihood of high pressures. On the other inand, the taller the chimey, the closer to the surface the pressure can act, so that even relatively low pressures my cause trouble. In subsequent parts of this repure we consider the effects of chiney hefght on pas preseure and containment. Chimsy height is expressed in terms of curity radius acesured fron the location of the explosive.

FIgure 9 show she tejerature rige of the chimey as a function of chimey helght, for variou: fractlons of the exploste eres dietributed throughout the chiney as hec. Esctures of the fraction of the explosive enersy ending up as hest in the fubble in the chiney range from 0.25 to 0.5 . Thene eatinates are baced on the observed temperature of the ses produced from the Casbusky chimey and eati-
Fip. 9. The relation between chimoly helpht, cxpressed in terms of cavit $\%$ radil, and chimey terperatire for three fractions of the explosive energy transmitted to the cinirney hv hizh-pressure gas. Explosive Yeld $418 \mathrm{TJ}$, cavit: radius $\left(R_{C}\right) 50 \mathrm{~m}$.

wates of chimney size. ${ }^{20}$ As the chimey height Increases, the tepperature rise decreases as a particular fraction of the explosive ezergy is depozited in the chimney as teat. This is khown in FIg. 9. For example, if the amblent temperature 18 $30^{\circ} \mathrm{C}$ and half the explostve energy becomes heat In a chimey $3 R_{c}$ high, the chimney cemperatute or 11 be $285^{\circ} \mathrm{C}\left(255^{\circ} \mathrm{C}\right.$ above amblent temperazure). If one-fourth of the explosive energy is in the chimey, the temperature will te $160^{\circ} \mathrm{C}$. For a fixed amount of gas in the chimey, the difference In pressure between these two cases w11 be proportional to the rat:s of the absoilute temperatures:

$$
\frac{285+273}{160+273}=1.3
$$

For a chimey height of $4 \mathrm{R}_{\mathrm{c}}$, this ratio decreeses to 1.2 ; at $5 \mathrm{z}_{\mathrm{e}}$, It $1 \mathrm{~s} 1.1$. Thus the precise enery frectionation is Important only for a chiney height of 
lese than about $4 \mathrm{R}_{\mathrm{c}}$. A chimey height of iess than $4 R_{c}$ is probably unlikely. In the pressure estimations presented in the rext section, one-fourth of the exployive energy is assumed to be in the chimney as heat.

\section{Gas Presnui e}

The pressure of gas resulting from a nuclear explosion in oil shale can be estimated by means of the equation

$$
\mathrm{P}=\mathrm{ZnRT} / \mathrm{V}
$$

where $z$ is the compressibility factor for the gas. It is approximately equal to unity for $\mathrm{H}_{2}, \mathrm{CH}_{4}$, and $\mathrm{CO}$ over the range of temperatures and pressures of interest. The compresability factor for $\mathrm{CO}_{2}$ is show In F1g. $10 . .^{21}$ at $50^{\circ} \mathrm{C}$, for example, $Z=0.62$ for $\mathrm{CO}_{2}$ at a pressure of $4 \mathrm{MPa}$. The other terms in Eq. (9) are defined as follows: $\mathrm{n}$ is the woles of $\mathrm{CO}_{2}$ (Table 2) plus joles of gas frow kerogen (Table 5); $T$ is the gas temperature in kelvins, giver. as a function of $\mathrm{R}_{\mathrm{c}}$ in Fig. 9, assuving $25 \%$ of the enerzy of the explosion heats the thimney (add $30^{\circ} \mathrm{C}$ for amblent temperature); ?. Is the gas conetant ( $\left.82 \mathrm{~cm}^{3}-\mathrm{atm} / \mathrm{mole}-\mathrm{K}\right)$; and $V$ is the vc. volume in the chimney, assumed to be equal to the savity volume:

$$
\begin{aligned}
\frac{4}{3} R^{3} & =\frac{4}{3}-(50 m)^{3} \\
& =5.23 \times 10^{5} \mathrm{~m}^{3} \\
& =5.23 \times 10^{11} \mathrm{~cm}^{3}
\end{aligned}
$$

It is conventent to contider the $\mathrm{CO}_{2}$ partial pressure in the chimey independencly of the other gasea for a conpressibflity factor can be applied to $\mathrm{CO}_{2}$

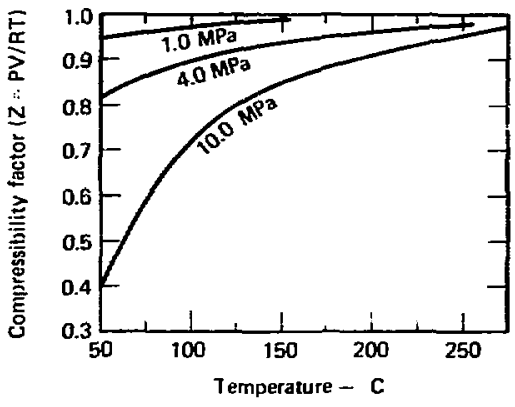

Ftg. 10. The compressibility of $\mathrm{Cn}_{2}$ as a function of tence-ittists ard pressure. When the partin] pressure of $\mathrm{CO}_{2}$ in the sas is the chinney is ereate: than about $\rightarrow$ SPa and che chimney temperature fs less than about $100^{\circ} \mathrm{C}$, the chimne pressure will be less than the pressure calculated by the ideal-gas 1 ak.

independent ly of the other gases in the chimey.

As en exzmple, the $\mathrm{CO}_{2}$ partial pressure in a large chinney is calculated. This represents a loi gas temperature and a cospressibility factor as dffierent fron unity as is probable. If $R_{c}-10$, the chimey temperature will be $55^{\circ} \mathrm{C}(328 \mathrm{~K})$. The count of $\mathrm{CO}_{2}\left(\mathrm{n}_{\mathrm{CO}_{2}}\right)$ is about $418 \cdot 10^{6}$ coles. Assuming $Z$ - 1 :

$$
\begin{aligned}
P_{\mathrm{CO}_{2}} & \approx\left(2 \mathrm{Rn} \mathrm{CO}_{2} \mathrm{~T}\right) / \mathrm{V} \\
& \approx 1.57 \times 10^{-10} \mathrm{nT} .
\end{aligned}
$$




$$
\begin{aligned}
& \approx\left(1.5 ; \times 10^{-39}\right)\left(4.28 \times 10^{6}\right)(32 d) \\
& =21.5 \mathrm{~atm} \\
& =2.15 \mathrm{kPa} .
\end{aligned}
$$

According to Fi\&. 10, the conpressibility factor for $\mathrm{CO}_{2}$ at a $\mathrm{CO}_{2}$ partial pressure of $2.15 \mathrm{MPa}$ and a teaperature of $55^{\circ} \mathrm{C}$ is about 0.91. This value is used to improve the estimate of the $\mathrm{CO}_{2}$ partial pressure:

$$
\begin{aligned}
P_{\mathrm{CO}_{2}} & =-.15(0.91) \\
& =1.96 \mathrm{MP}=
\end{aligned}
$$

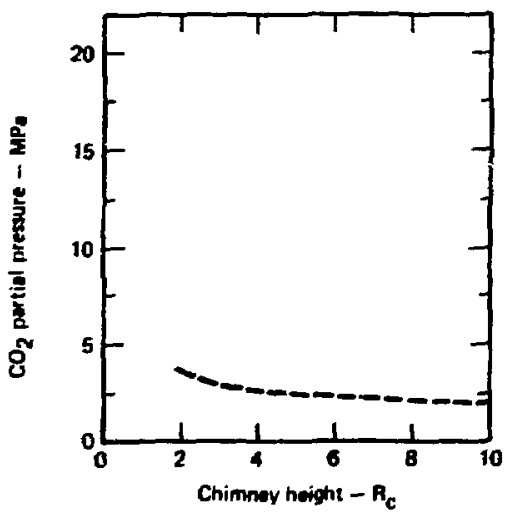

Fip. 11. Partinl preseure of $\mathrm{CO}_{2}$ in the chimay estinated for the case of 418-TJ explaston in oI 1 shale conteining 15 wtz $\mathrm{CO}_{2}$. covity radius $50=$. hindenpyrolysis ans not included. Cne-fourth of the exploilve energy it sasued to hewt the robble in the chimey.
Figure 11 shows the partial pressure of $\mathrm{CO}_{2}$ 1t. the chimney calculated in this way.

The pressure of kerogen-derfued gas in the chimey can be estirated in a similat way. However, since this gas is not as coxpresstble as $\mathrm{CO}_{2}$, the compressibility factor can be ignored. Accorcing to Table 5, a 418-IJ nuclear explogion w111 release $189 \times 10^{6}$ moles of gas from ofl shale containing $1 \mathrm{wt} \%$ kerogen. The pressure produced by this gas will depend on the chimney height and the kerogen conttent, as shown in FIg. 12. (The chinney is assumed to be heated by 257 of the explosive energy.)

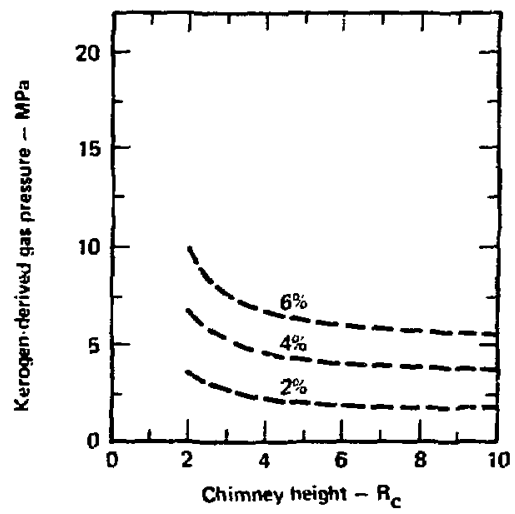

Fig. 12. Pressure of noncondensable fas released by pyroly's and reactlong of kerogen in ofl shale as a function of chimney height (chtmey remperature) and kerogen conient (Indicated by the percentages on the surves). Cnefourth of the explosive eneigy Is assuned to be in the chimney. Char is assumed to react with ateam at temprature: ahove about $1000^{\circ} \mathrm{C}$. 


\section{Contuinumat}

The gas pressure rasulting from a nuclear explosion in oil shale can be estimated. How is this pressure related to containment? Most of the studies on contalnment have been concerned with shortterm dynanic effects. We have not had experience with a sustained gas piessure because sur work was conducted under conditions where (1) little noncondensable gas was generated (aee $\mathrm{Fig}$. 1) or (2) the gas that was zenerated, tostly frow carbonates in fermeable rocki, escaped from the shimney and was retained underground by air displacenent.

He need to know what sustained fIuld preasure can be tolerated at depth without cracking rock. It is comon prastice to use fluid pressure at depth to crack =ock to aid in the recovery of oll and gas. Fludd preseures in the range of 1.2 to 1.5 tiaes the 11thostatic pressure are used to initlate fracture, and then fluid pressures below the 11thostatic pressure ( 0.6 times the 11thostatic pressure) are sustained to extend the fracturing.

A reasonable may to begin evaluating the containment of a nuclear explosion is to compare the estimated gan prassure to the lithostatic and hydrostatic pressures at the top of the chimey, for that is the polat nearest the surface where the presoure 1s applied. Figure 13 shows the depth to the top of the chinney for a 418-TJ explosion at 823 a based on a cavity radius of $50 \mathrm{~m}$. Figure 14 shore the IIthoatstic and hydrostatic pressures at a function of chinney height expressed in terms of cavity radil. Figure 15 contelns the save Infornation and, in addition, shows the gat

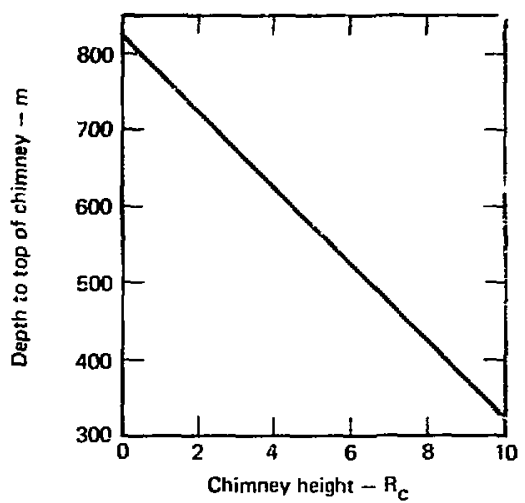

Fig. 13. Depth to the top of the chimne" for a 418-TJ explosion at $823 \mathrm{~s}$, assuning a cavity radius of $50 \mathrm{~m}$.

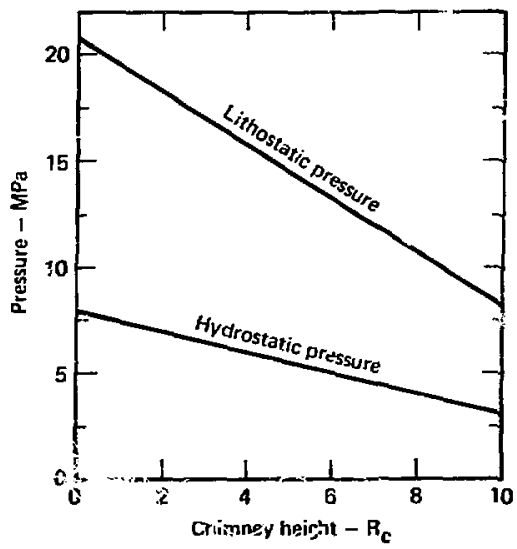

Fig. 14. i...chostat1c and hydrostatic prasisures at the cop of a sinimey as a function of chimney height. Based on a 50-m cavity radius resulting from a $418-T J$ explosion at a depth of $823 \mathrm{~m}$. 


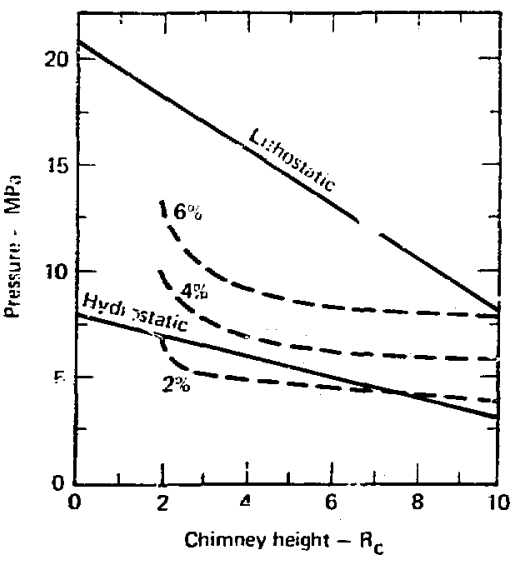

pressure resulting from a 418-IJ nuclear exp1osion in ofl shales containing 15 wt\% $\mathrm{CO}_{2}$ and 2,4 , and 6 wt\% kerogen. This figure shows that the gas piessure for the case of 2 wtz kerogen more or less follows the hydrostatic pressure, independently of
TH. 15. Total sas pressute foe a $418-T J$ nuclear explesion in an ofl shale contafois: $15 \mathrm{wt}^{\mathrm{C}} \mathrm{CB} 2$ as a function of chimney hefgit and keroger cortent (indicated by the pervestapes an the curves).

\section{Conclasions and Recommendations}

Nuclear explosions deep in the Plceance Creek Basin will generate a locg-term gas pressure lower than the hyd ostatic pressure if the kerogen content of the shale near the site of th 2 explosion is less than 2 wt\%. In this context, "near" meais ciose enougt to be heated by the explosion. about $330 \times 10^{9}$ B of ofl shile can he heated to $300^{\circ} \mathrm{C}$ and above by a $418-\mathrm{TJ}$ explosfon, as shown in Table 2. The volatile-matter content of ofl shale, particularly the kerogen content, within about $30 \mathrm{n}$ of the location of the explosive is of importance to containment. It 1s the ofl thale within this distance that may be the chiliney height over the zange of $2 R_{c}$ to $10 \mathrm{k} z$. The pressure at the top of the chimney approaches the lithostatic pressure only in the case of both high chimneys $\left(>10 R_{c}\right)$ and kerogen corwentrations in excess of 6 wt $\%$. heated to about $300^{\circ} \mathrm{C}$ and above and may produce gas.

One of the most important, and least certain, assumptions ande in this work is the high-temperature pyrolysis of keragen to hydrogen and the reaction of the remaining char with steam. Some perhaps a large fraction, of the kerogen my form hydrocarbon vapors, which can condense in the cooler parts of the chimney. Even the kerogen in oll stale heated to $1200^{\prime} \mathrm{C}$ may eacape completa prolysis to hydrogen and char, tepending on the rate at which it 1 s heaced. We also cannot be certain thas: nufficlent steall will be avallable to react 
wth char. This is particularly true as the kerogen content increases. One cinnot asstine that a nuclear explosion in oi shaie containing 10 wt\% kerogen will aroduce twice as wuch gas as an explosion in shale contalning 5 wt\% kerogen.

The assumption has been made that no gas leaks out of the chimney. Some gas leakage is probable, particularlo in the leached zones in the rasin. The maximum gas pressure that can be sustained will depend on the relative rates of gas loss and gas generation. In subsequent work on contaimment in oil shale, spectfic sites should $\because$. sousidered and the fas permeabilfEv rc..:ired in order to take gas leakage in: sccount.

We can ritce some estimates of the rate of gas k:meration. From 50 to $70 \%$ of the : tal ascunt of noncondensable gas comes ron rock that is relted $\left(\mathrm{T}>1200^{\circ} \mathrm{C}\right)$. The r.lzase $\because$ gas from melced rock ts rapid, but we do not know far how lonf: a time after a nucieat explcsion additional rock is betng melted. Ke need to learn more I out the length of time rocks are heated $\because$ rarlous temperatures b; a nuclear explo-

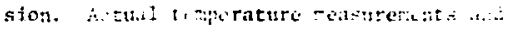

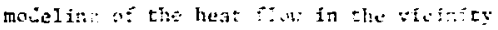
of nuclear explosions are needed, partict:lar:Iy in the cise of explosions with yitis in excess of $200 \mathrm{TJ}$ in relitively dry rock. Some insigint irta the thermil history of nuclear explosions has cowe foon the analysis of gas samples collected at varílous places and tires afrer nuclear explosions. The amount and composition oi tre gas observed ifter explosions have been compared to the amount and composition of guses released by heating samples of the same rock in the laboratory. This approach has been particularly useful in the recent Rio Blanco experiment. 8

A containment experiment designed to simulate the unusual features of a suclear explosion in ofl shale is essential. Such an experfment would be carried out in a gas-generating but impermeable rock. The experiment would be instrumented to measure pressure, temperature, and to sample gases as a function of time. The rock should be a fine-grained mixture of silicates and carbonales (e.g., marlstcne) to simulate the irreversible gas release by carhonates In oil shale. 


\section{Hefereneses}

1. The Eronco OfI Shale Study, prepared by the 1.S. Atomic Energy Comisston, the t. S. Department of Interior, the CER Ceoncclear Corp., and the Lawrence Radiation Laboratory. f Availaine from the Natfonal Technical Infordation Centei. U.S. Departzent of Conmerce, Springfield, Va. 22151.)

2. Project ttah, Stmposiur on oil Shale Fetorting and Project ttak, Laramie, bo., February 1971 (hestern Oil Shale publicaticr).

3. A. E. Lewris, Niclear In-Situ Recovery ef Oil from 011 Shale, Lawrence IJvertore i.aboratory, Rept. LCRI_-51453 (1973).

4. A. E. Lewis, The Outlook for Oil Shale, Lawrence LIvermore Laboratory, Rept. UCRL-75241, Rev. 1 (1974). (Fublished in the Proceedings of the AAs 5 an Francisco Meeting, 1974.)

5. D. E. Rawson, R. h. Tayior, and D. L. Springer, Naturutssenschaften 34,525 (1967).

6. Project Gnone, Final Report, Rept. PNE-126-F, U.S. Department of Comerce, Feather Bureau Research station, Las Vegas (1961).

7. C. F. Smith, Trans. Am. Nuc1. Soc. 14, 690 (1971).

8. R. H. Taylor, D. h. Eowen, and P. E. Rossler, Heating Effects In Rlo Blanco Rock, Lawrence LIvermore Laboratory, Rept. CCRL-76129 (1974).

9. P. L. Coffin, F. A. Welöer, and R. X. Gianzman, Ceohydrology of the Plceance Creek Struciural Basin, X.K. Colorado, L.S. Geological Survey AtIas HA-37G (1971: .

10. R. W. Taylor, Nucl. Technol. 18, 185 (1973).

11. T. T. Butkovich, Rock Nelt from an tinderground Nuclear Explosion, Lawrence Livermore Laboratory, Rept, tICRL-5144 (1974).

12. D. D. ¿ackson, Lawrence Liverwore Laboratcry, personal commication (1974).

13. S. P. Clark, Jr., Ed., Handbook of Physical Constonts, the Geological Soclety of Amertca, Inc., Yenotr $97(1966)$.

14. D. R. Stephens and i. M. Lilley, "Loadinf-Lnloading Pressure-Volume Curves for Rocks," paper presented at the American Suclear Socjety Toplcal Meeting, "Eng1neerlag with Nuciear Explosives," Las Vegas, 1970. (Avallable from the National Technical Information Center, v.s. Department of Comerce, Springfield, Va. 22151.)

15. R. W. Taylor, Release of Gas frnp Heated ofl Shale and from Nixtures of Dolont and Quartz, Lawrence LJvermore Lahoratory, Rept. LCRL-51838 (1975).

16. J. W. Swith, witimate Composition of Organic Macerfal in Freen Rivez O11 Shale, U.S. Bureau of Mines. Rept. RI-7248 (1969).

17. K. E. Stanfield et 21. Propertles of Colorado O1l Shale, U.S. Bureau of Hines, Rept. RI-4825 (1951).

18. T. R. Butkoul hh and A. E. Lew's, Alds for Estluating Effects of Underground Nuclear Explosione, Lawrence Liverwore Laboratory, Rept, UCRL-50929, Rev. 1 (1963). 
19. T. H. East and E, D. Gardner, Oil Shale Mining, R1fle, Colorado 1944-1956, U.S. Bureau of Mines, Bulletin 611 (1964).

20. D. E. Parks and L. A. Rogers, "Prelfminary Predictions of Wagon theel chimney Temperature," in Prcject Wagon Whee:l, L.A. Rogers, Ed., Technical Studtes Rept. No. 2 (El Paso Natural Gas $\mathrm{Co}_{0}, 1972$ ).

21. J. Hilsenreth et al., Tables of Thermodynamic and Transfort Prok ties (J'ergamon Press, New York, 1960). 